\title{
Evaluation of Different PCR Systems for the Detection of Mycoplasma gallisepticum in Chicken Trachea
}

\author{
Serpil Kahya Demirbilek \\ Uludag University, Faculty of Veterinary Medicine, Department of Microbiology, Bursa, Turkey
}

Geliş Tarihi / Received: 19.04.2017, Kabul Tarihi / Accepted: 17.05.2017

\begin{abstract}
In this work, we detected the MG-serologic condition by rapid plate agglutination tests, used Air Thermal Cycler (ATC PCR) (Idaho Technologies) and LightCycler real-time PCR system (LC PCR) (Roche Diagnostics, Manheim, Germany) for rapid and reliable detection of Mycoplasma gallisepticum (MG) from tracheal swab samples of naturally infected breeder chickens, and determinated MG-DNA detection limit by MG LC PCR from both pure culture and artificially spiked samples. One hundred and seventy seven tracheal swab samples from 16 flocks of 3 different companies were tested by LC PCR. Despite 117 chickens from 10 flocks were diagnosed as MG-seropositive, only 41 $(35 \%)$ of tracheal swab samples from 3 (\%30) flocks were found positive by LC PCR. Sixty (33.8\%) of the samples from 6 MG-seronegative flocks were also found to be MG negative by LC PCR. Two hundred twelve MG-seropositive samples from 4 companies ( 3 of them are same companies tested previously by LC) were tested by ATC PCR and detected only 4 (1.8\%) tracheal swab samples MG-positive. The LC PCR gives the results in approximately 6 hours DNA extraction, and is rapid and reliable confirmation and detection test ready to be implemented for screening MG-infected flocks in poultry companies.
\end{abstract}

Key words: Chicken, Mycoplasma gallisepticum, PCR

\section{Farklı PCR Sistemlerinin Tavuk Trakeasından Mycoplasma gallisepticum Tespiti için Değerlendirilmesi}

\begin{abstract}
Özet: Bu çalışmada, Mycoplasma gallisepticum (MG) ile doğal enfekte damızlık tavuklarda kümeslerin MG seropozitivitesine çabuk serum aglütinasyon testiyle bakıldı, MG-DNA'sının tespitinde; Air Thermal Cycler (ATC) PCR (Idaho Technologies) ve hızlı, güvenilir bir metot olan LightCycler real-time PCR sistemleri (LC PCR) (Roche Diagnostics, Manheim, Germany) kullanıldı ve MG LC PCR'ın hem saf kültür ve hem deneysel olarak kontamine edilmiş örneklerden MG DNA'sını tespit etme limiti belirlendi. Üç farklı firmaya ve 16 kümese ait 177 trakeal swap LC PCR ile çalışıldı. On kümesten 177 tavuk MG-seropozitif olarak teşhis edilmesine rağmen bunlardan sadece 3 (30\%) kümesten alınan 41 (\%35) tracheal örnek LC PCR ile pozitif bulundu. Altı MG-seronegatif kümesten alınan 60 örnek (\%33.8) aynı zamanda LC PCR ile de MG negatif olarak bulundu. Daha önce aynı kümeslerin de dahil olduğu 4 farklı firmadan alınan 212 MG-seropositive örneklerden sadece 4 tanesi (\%1.8)'i ATC PCR ile pozitif bulunmuştu. Geliştirdiğimiz LC PCR, DNA ekstraksiyonu ile birlikte yaklaşık olarak 6 saatte sonuç vermektedir. Aynı zamanda kanatlı işletmelerinde MG-enfekte kümeslerin taranmasında kullanılabilecek hızlı ve güvenilir, hazır bir tespit ve doğrulama sistemidir.
\end{abstract}

Anahtar kelimeler: Tavuk, Mycoplasma gallisepticum, PCR

\section{Introduction}

Mycoplasma gallisepticum (MG) is a well-known cause of economically important diseases of domesticated chickens and turkeys [11]. MG account for substantial financial losses, owing to decreased egg production and increased mortality, as well as to additional costs for prevention and control of diseases [5]. MG can be transmitted vertically to affect progeny individually and can be spread horizontally to uninfected birds [13]. The flock screening is done by serological assays and the confirmation can be done by cultivation, recombinant DNA probes or polymerase chain reaction (PCR) [15]. A presumptive Serum Plate Agglutination (SPA) test is routinely used for diagnosis of MG infection of chickens. However this test has drawbacks, the most important one being that seroconversion behind infections require a minimum of 1 week after infection for antibodies to be detected in agglutination and up to 3 weeks for positivity in Hemagglutination Inhibition (HI) test [6].

The gold standard for MG detection is the isolation and/or identification of the organism [12] However, both procedures can take 10-20 days and 
sometimes is unproductive because of overgrowth by bacteria or because of suppression effect by antibiotic therapy [15], and often have problems with specificity and sensitivity [16].

Real-Time PCR is one of the most sensitive methods for detecting and quantitating DNA, especially for low-abundance templates. Also, melting curve analysis after PCR enables identification of the specific PCR product [8]. With this approach, we were able to monitor the amplification of the newly synthesized MG-specific PCR product as a proportionally increasing fluorescent signal by using the double-stranded DNA binding dye SYBR Green I, for detecting MG in chicken tracheal swabs [4] by LightCycler (LC) PCR system.

In this work, we tested tracheal swab samples to optimize and detect MG by LC PCR system and Air Thermal Cycler (ATC) system.

\section{Material and Methods}

\section{Bacterium and culture media}

Mycoplasma gallisepticum S6 strain was kindly obtained from Pendik Veterinary Research Institude, İstanbul, Turkey. Strain propagation and numerations were applied in Mycoplasma broth (Frey) (BD, Cat no: 212346) and PPLO agar base (Mycoplasma agar base) (BD, Cat no: 211456).

\section{Field samples}

Tracheal swabs were taken by scraping the mucosal surface of the trachea, partially cut off and put in microcentrifuge tubes containing $1 \mathrm{ml}$ sterile physiological saline water and transferred to the laboratory. 212 live chickens belonging to 4 companies, with no antibiotic treatment, which were found to be seropositive by RPA tests, were tested by ATC PCR in first 2 year. Than, 177 samples of 16 flocks, with no antibiotic treatment from 3 different companies were tested with LC PCR.

\section{Primers}

The PCR primers (MG1 and MG2) were selected from a region within the sequence of MG lipoprotein gene partial codons, as previously described [4] to amplify the $400 \mathrm{bp}$ product.

\section{MG Serology}

RPA(rapid plate agglutination tests) were performed using MG antigen (Soleil MG RPA-test) with sera samples. Sera and antigen were pre-heated to room temperature before used.

\section{Isolation of DNA}

MG S6 strain DNA and all tracheal swab DNAs were isolated with QIAMP DNA mini kit (QIAGEN Cat no: 51304 , Germany), and $2 \mu 1$ was used as template in PCR.

\section{LC PCR}

Each reaction had a volume of $20 \mu 1$ including 18 $\mu 1$ of reaction mixture containing $1 X$ FastStart DNA SYBR Green I Master Mix (Roche), $\mathrm{MgCl} 2$ (4 $\mathrm{mM}$ ), and $0,5 \mu \mathrm{M}$ concentriation of each primer and $2 \mu 1$ of template DNA. Cycling parameters were: Initial denaturation at $95^{\circ} \mathrm{C}$ for $10 \mathrm{~min}$; followed by 40 cycles of denaturation at $95{ }^{\circ} \mathrm{C}$ for $10 \mathrm{sec}$, annealing at $50{ }^{\circ} \mathrm{C}$ for $5 \mathrm{sec}$, and extention at $72{ }^{\circ} \mathrm{C}$ for $20 \mathrm{sec}$. melting curve analysis was automatically performed by LightCycler 2.0 Software (Version 3), and the melting peaks were expected to have melting temperature $(\mathrm{Tm})$ of $80^{\circ} \mathrm{C}$.

\section{ATC PCR}

Each reaction contained; $2.5 \mu 110$ X MG PCR buffer (Roche), $0.3 \mu 1$ Taq polymerase (Roche), $0.5 \mu 1$ dNTP (Roche), $2 \mu \mathrm{l}$ of each primer $(50 \mathrm{pmol} / \mu \mathrm{l})$, $1.5 \mu 1 \mathrm{MgCl} 2$ (25 mmol/ $\mu \mathrm{l})$ (Roche), $16.7 \mu \mathrm{l} \mathrm{PCR}$ grade water, and $2 \mu 1$ template with cycling parameters as indicated above.

\section{Template preparations for detection limit determination from pure culture and artificially spiked samples}

For detection limit determination from pure culture, tenfold dilutions of stock MG S6 strain culture, with an initial concentration of $108 \mathrm{CFU}$ ml-1, were prepared up to 101 in Mycoplasma broth (Frey). $100 \mu$ was taken from each dilution in $900 \mu 1$ sterile physiological saline water and vortexed. Suspensions were transferred to $1.5 \mathrm{ml}$ microsantrifuge and their DNAs were isolated. For detection limit determination with artificially spiked samples, tracheal swabs artificially spiked with MG S6 strain were used. For this, $100 \mu \mathrm{l}$ of ten fold dilutions from 108 to 101 CFU ml-1 of MG S6 strain culture was mixed indi- 
vidual tracheal swabs were rinsed in $900 \mu 1$ sterile saline water and vortexed $2 \mathrm{~min}$. Swabs were discarded and $2 \mu 1$ of the DNA was used as template in PCR.

\section{Results}

Detection limit of LC PCR with pure MG S6 strain culture and with artificially spiked samples

Sensitivity was found 1 and $100 \mathrm{CFU}$ ml-1 with pure MG S6 strain culture and artificially spiked samples, respectively.

\section{Specifity of LC PCR}

PCR yield specific Tm peaks of $78.4-80^{\circ} \mathrm{C}$ with all MG strains and all seropositive field samples, tested.

\section{ATC PCR and LC PCR with field samples}

One hundred and seventy seven tracheal swab samples from 25 flocks from 3 different companies were tested by LC PCR (Table1). Despite 117 chickens from 10 flocks were diagnosed as MG-seropositive only $41(35 \%)$ of tracheal swab samples from 3 flocks were found positive by LC PCR. Sixty $(33.8 \%)$ of the samples from $6 \mathrm{MG}$-seronegative flocks were also found to be MG negative by LC PCR. Two hundred twelve MG-seropositive samples from 4 companies ( 3 of them are same companies tested previously by LC) were tested by ATC PCR and detected only 4 (1.8\%) tracheal swab samples MG-positive (Table 2).

Table 1. MG LC PCR results of seropositive and seronegative samples from flocks tested

\begin{tabular}{cccccc}
\hline Sample number & Company & $\begin{array}{c}\text { Number of } \\
\text { total flocks }\end{array}$ & $\begin{array}{c}\text { Number of } \\
\text { total samples }\end{array}$ & $\begin{array}{c}\text { Number of positive } \\
\text { flocks/serology }\end{array}$ & $\begin{array}{c}\text { Number of } \\
\text { positive samples }\end{array}$ \\
\hline 1 & $\mathrm{~A}$ & 1 & 20 & $0 /-$ & 0 \\
2 & $\mathrm{~B}$ & 8 & 54 & $1 /+$ & 25 \\
\hline 3 & $\mathrm{C}$ & 4 & 26 & $0 /-$ & 0 \\
4 & $\mathrm{C}$ & 1 & 43 & $1 /+$ & 11 \\
\hline 5 & $\mathrm{~B}$ & 1 & 14 & $0 /-$ & 0 \\
6 & $\mathrm{~A}$ & 1 & 20 & $1 /+$ & 5 \\
\hline Total & $\mathbf{3}$ & $\mathbf{1 6}$ & $\mathbf{1 7 7}$ & $\mathbf{3}$ & $\mathbf{4 1}$ \\
\hline
\end{tabular}

Table 2. MG ATC PCR results from seropositive field samples

\begin{tabular}{ccc}
\hline Sample number & Company & $\begin{array}{c}\text { ATC PCR result/number } \\
\text { of samples tested }\end{array}$ \\
\hline 1 & $\mathrm{~A}$ & $-/ 15$ \\
2 & $\mathrm{~B}$ & $-/ 6$ \\
\hline 3 & $\mathrm{C}$ & $1(+) / 10$ \\
\hline 4 & $\mathrm{~B}$ & $-/ 2$ \\
\hline 5 & $\mathrm{~B}$ & $-/ 10$ \\
\hline 6 & $\mathrm{~A}$ & $-/ 5$ \\
\hline 7 & $\mathrm{~B}$ & $-/ 14$ \\
\hline 8 & $\mathrm{~B}$ & $-/ 21$ \\
\hline 9 & $\mathrm{~A}$ & $-/ 13$ \\
\hline 10 & $\mathrm{~B}$ & $-/ 25$ \\
\hline 11 & $\mathrm{C}$ & $1(+) / 14$ \\
\hline 12 & $\mathrm{~B}$ & $-/ 11$ \\
\hline 13 & $\mathrm{~A}$ & $-/ 10$ \\
\hline 14 & $\mathrm{C}$ & $1(+) / 11$ \\
\hline 15 & $\mathrm{~A}$ & $-/ 10$ \\
\hline 16 & $\mathrm{D}$ & $1(+) / 35$ \\
\hline Total & 4 & $\mathbf{4} / 212$ \\
\hline
\end{tabular}

\section{Discussion}

In this study, we found that serology had higher sensitivity than LC PCR and ATC PCR. This can be explained by the presence of nonspecific agglutinations related to immunization with oil-adjuvenated vaccines, presence of either non-pathogenic Mycoplasma strains or other pathogenic Mycoplasma species in chickens [2,7]. Also this type of high reactor rate results can be related to the use of agglutination tests, which would occasionally give false positive responses due to their high sensitivity. Therefore, samples from seropositive flocks should absolutely be retested/confirmed by bacteriology or PCR as indicated [1]. Ley [11] and Lauerman [10] have indicated that infections caused by atypical MG strains might not be detected by SPA or HI tests, in which the antigens of the standard reference MG strains are used. This situa- 
tion was related to the possible difference in antigenic make-up or tissue tropism of MG field strain leading to lower virulence and weaker antibody response, but still be detectable by PCR [9].

We observed a relatively higher detection sensitivity with pure culture than previously reported [4], where the authors indicated that this might have arisen from some inhibitory substances in tracheal swabs effecting template quality in PCR. In this study, we used a commercial DNA isolation kit, which enable us to obtain a standard quality template DNA and increased the sensitivity of LC PCR assay. Use of similar isolation kits to obtain template DNA for PCR have also been reported in several other studies $[3,9,10,14]$.

We were able to detect MG specific PCR product in 25-30 minutes directly from crude DNA templates extracted from tracheal swabs of infected chickens. We have observed that there was a higher correlation between SPA and PCR positivity in LC than ATC PCR, indicating the superiority of LC specificity and sensitivity over ATC PCR. We conclude here that this optimized LC PCR is specific and sensitive enough to be reliably used for the detecting/screening MG-infected flocks.

This work was presented and published in 2 . Mediterranean Poultry Summit of World of Poultry Science Association proceeding book.

\section{References}

1. Anonymous (2008). Manual of Diagnostic tests and vaccines for terrestrial animals. Chapter 2.3.5. Avian Mycoplasmosis (Mycoplasma gallisepticum, M. synoviae). http://www. oie.int/eng/normes/manual/2008/pdf/2.03.05_\%20avian MYCO.pdf

2. Avakian AP, Kleven, SH, Glisson, JR, (1988). Evaluation of the specificity and sensitivity of two commercial enzymelinked immunosorbent assay kits, the serum plate agglutination test and the hemagglutination-inhibition test for antibodies formed in response to Mycoplasma gallisepticum. Avian Dis. 32, 262-272.

3. Callison SA, Riblet SM, Sun S, Ikuta N, Hilt D, Letting V, Kleven SH, Suarez DL, Garcia M, (2006). Development and validation of a real-time Taqman polymerase chain reaction assay for the detection of Mycoplasma gallisepticum in naturally infected birds. Avian Dis. 50, 527-544.
4. Carli KT, Eyigor A, (2003). Real-time polymerase chain reaction for detection of Mycoplasma gallisepticum in chicken trachea. Avian Dis. 47, 712-717.

5. Garcia M, Jackwood MW, Leviohn S, Kleven SH, (1995). Detection of Mycoplasma gallisepticum, Mycoplasma synoviae and Mycoplasma iowae by multi-species polymerase chain reaction and restriction fragment length polymorphism. Avian Dis. 39, 606-612.

6. Garcia M, Ikuta N, Levisohn S, Kleven SH, (2005) Evaluation and comparison of various PCR methods for detection of Mycoplasma gallisepticum infection in chickens. Avian Dis. 49, 125-132.

7. Glisson JR, Dawe JF, Kleven SH, (1984). The effect of oilemulsion vaccines on the occurance of nonspecific plate agglutination reactions for Mycoplasma gallisepticum and Mycoplasma synoviae. Avian Dis. 28, 397-405.

8. Harasawa R, Mizusawa H, Fuji M, Yamamoto J, Mukai H, Ueomori T, Asada K, Kato I, (2005). Rapid detection and differentiation of the major Mycoplasma contaminants in the cell cultures using Real-Time PCR with SYBR Green I and melting curve analyses. Microbiol İmmunol. 49, 859863.

9. Kleven SH, (1998). Mycoplasmas in the etiology of multifactorial respiratory diseases. Poult Sci. 77, 1146-1149.

10. Lauerman LH, (1998). Mycoplasma PCR assays, In. Lauerman LH (Ed) Nucleic Amplification Assays for Diagnosis of Animal Disases, American Association of Veterinary Laboratory Diagnosticians, Auborn, AL, USA, pp. 41-52.

11. Ley DH, Berkhoff JE, McLaren JM, (1996). Mycoplasma gallisepticum isolated from house finches (carpodacus mexicanus) with conjunctivitis. Avian Dis. 40, 480-483.

12. Ley DH, (2003). Mycoplasma gallisepticum infection. In: Saif YM, Barnes HJ, Fadly AM, Glisson JR, McDougald LR \& Seayne DE (Eds), Diseases of Poultry. Ames, Iowa State University Press, USA, 11th ed., pp. 122-144.

13. Moscoso H, Thayer SG, Kleven SH, (2004). Materials and methods optimization and application of PCR for detection of Mycoplasma gallisepticum and Mycoplasma synoviae. Avian Dis. 48, 841-850.

14. Raviv Z, Kleven SH, (2009). The development of diagnostic real-time PCR's for the four pathogenic avian Mycoplasmas. Avian Dis. 53, 103-107.

15. Silveria RM, Fiorentin I, Marques EK, (1996). Polymerase chain reaction optimization for Mycoplasma gallisepticum and M. synoviae diagnosis. Avian Dis. 40, 218-222.

16. Slavik MF, Wang RF, Cao WW, (1993). Development and evaluation of polymerase chain reaction method for diagnosis of Mycoplasma gallisepticum infections in chickens. Mol Cell Probes. 7, 459-463. 